Fall 1988

\title{
The Rise and (Coming) Fall of Efficiency as the Ruler of Antitrust
}

Robert H. Lande

University of Baltimore School of Law, rlande@ubalt.edu

Follow this and additional works at: http://scholarworks.law.ubalt.edu/all_fac

Part of the Antitrust and Trade Regulation Commons

\section{Recommended Citation}

The Rise and (Coming) Fall of Efficiency as the Ruler of Antitrust, 33 Antitrust Bull. 429 (1988)

This Article is brought to you for free and open access by the Faculty Scholarship at ScholarWorks@University of Baltimore School of Law. It has been accepted for inclusion in All Faculty Scholarship by an authorized administrator of ScholarWorks@University of Baltimore School of Law. For more information, please contact snolan@ubalt.edu. 


\title{
The rise and (coming) fall of efficiency as the ruler of antitrust
}

\author{
BY ROBERT H. LANDE*
}

Antitrust policy cannot be made rational until we are able to give a firm answer to one question: What is the point of the law-what are its goals? Everything else follows from the answer we give.

R. BoRk, The Antitrust Paradox at 50 (1978)

The debate over the legitimate goals of antitrust is ceaseless and its practical resolution influenced by politics. The answer often given in the past, and particularly during the Warren Court era when a heavy emphasis was placed on social and political factors, contrasts sharply with the consensus view during the Reagan Administration that only economic efficiency counts. Since antitrust moves in cycles, a natural question arises-will antitrust

* Assistant Professor, University of Baltimore School of Law.

AUTHOR'S NOTE: I am grateful to Alan Fisher, Ernest Gellhorn, Douglas Ginsburg, John Kirkwood, William Kovacic, James Ponsoldt, Steven Salop and Joe Sims for extremely valuable comments. I also appreciate the excellent research assistance of Anita Purcell and Conrad Sump. Mistakes, of course, are my own. 
continue to stand upon a foundation of efficiency, return to the old social and political perspective, or embrace some third view of its proper direction?

This article will trace the genesis of the efficiency approach to antitrust and attempt to predict its future. Although the efficiency approach has triumphed over the social and political view through clever articulation and a promise of superior implementation and predictability, it too is likely to be replaced, by a "price to consumers" or "wealth transfer" standard. This new approach asserts that the antitrust laws were enacted to give consumers the right to purchase competitively priced goods. ${ }^{1}$ It condemns the use of market power to artificially raise prices and stresses that the antitrust laws were designed to prevent wealth extractions from consumers by firms with market power. Consumers, not cartels, were given the fruits of competitive capitalism. This article asserts that the wealth transfer approach is starting to replace the efficiency standard and eventually will succeed at implementing Congressional populist sentiment in an administrable, predictable manner.

\section{The rise of economic efficiency}

\section{A. Bork's "strict constructionist" view of the legislative history}

The view of the goals of the antitrust laws that almost universally prevailed until less than a generation ago was decidedly populist. Various social and political goals were deemed important to the antitrust laws' framers. These included the prevention of industrial concentration, ${ }^{2}$ the reduction of the political

1 This article will argue that Congress, in passing the antitrust laws, helped to define the property right that we today term "consumers surplus," and awarded this property right to consumers. Congress condemned the uncompensated taking of this property right by firms with market power.

2 Arnold, The Economic Purpose of the Antitrust Laws, 26 Miss. L.J. 207, 207-08 (1955). 
influence of large firms and promotion of individual liberty, ${ }^{3}$ the promotion of small business and the creation of entrepreneurial opportunity. ${ }^{4}$ The social and political view held center stage virtually until the advent of the Reagan Administration, ${ }^{5}$ and appears to have breathed its dying gasp only under the administration of Chairman Pertschuk, head of the Federal Trade Commission during the Carter Administration. ${ }^{6}$

Few antitrust scholars believe that antitrust should return to a Warren Court approach based largely upon social and political concerns. ${ }^{7}$ Today there is a consensus that this type of antitrust was far too interventionist. In addition to overly strict substantive standards, the excesses included the practical problems that inevitably arose in the implementation of a relatively

3 See, e.g., Blake \& Jones, In Defense of Antitrust, 65 Colum. L. REV. 377, 377-82 (1965).

4 Id. at 382-84; Elzinga, The Goals of Antitrust: Other Than Competition and Efficiency, What Else Counts? 125 U. PA. L. REv. 1191 (1977).

5 Many moderate and liberal antitrust academics began to move away from the social and political orientation well before 1980. Many politicians, antitrust enforcers and judges were, however, somewhat slower to rely completely upon economic analysis.

6 See, for example, M. Pertschuk, Chairman, Federal Trade Commission, Remarks at The Eleventh New England Antitrust Conference, Boston, Massachusetts 10 (November 18, 1977):

[A]lthough efficiency considerations are important, they alone should not dictate competition policy. Competition policy must sometimes choose between greater efficiency, which may carry with it the promise of lower prices, and other social objectives, such as the dispersal of power, which may result in marginally higher prices. In 1977, no responsive competition policy can neglect the social and environmental harms produced as unwelcome by-products of the marketplace: resource depletion, energy waste, environmental contamination, worker alienation, the psychological and social consequences of marketing stimulated demands.

7 See, e.g., sources cited in Fox, The Modernization of the Antitrust: A New Equilibrium, 66 CORNell L. Rev. 1140 (1981). 
amorphous social/political orientation. These problems helped make the antitrust world receptive to a more conservative alternative that promised superior implementation, clarity and predictability.

If one scholarly work were singled out for credit for launching the efficiency-oriented view of antitrust it would surely be the seminal 1966 article by (then) Professor Robert Bork, ${ }^{8}$ the foundation for both his own 1978 masterwork ${ }^{9}$ and the views of countless other conservative scholars. ${ }^{10}$ Bork asserted that his analysis was a strict constructionist view of the legislative history of the Sherman Act. In a lengthy, heavily footnoted text he developed the argument that the original framers of the Sherman Act had a single intent: to enhance economic efficiency. Bork argued that "[t]he whole task of antitrust can be summed up as the effort to improve allocative efficiency without impairing productive efficiency so greatly as to produce either no gain or a net loss in consumer welfare." "Bork further asserted that there was "not a scintilla of support" in the Act's legislative history for "broad social, political, and ethical mandates." 12 Bork explicitly rejected distributive (i.e., wealth transfer) issues

8 Bork, Legislative Intent and the Policy of the Sherman Act, $9 \mathrm{~J}$. L. \& ECON. 7 (1966). For a more complete analysis of Bork's legislative history conclusions see Lande, Wealth Transfers as the Original and Primary Concern of Antitrust: The Efficiency Interpretation Challenged, 34 HASTINGS L.J. 65 (1982).

9 R. Bork, The Antitrust Paradox (1978).

10 For example, R. Posner, Antitrust Law: An Economic PerspecTIVE 8-23 (1976) did not undertake a detailed analysis of the Sherman Act's legislative history. He instead approvingly cited Bork for the argument that Congress intended that only economic efficiency play a role in antitrust. For other examples, see Lande, supra note 8, at 67-69.

In addition, Posner believes that monopoly profits may not exist; what would otherwise be the transfer may be transformed into inefficiency through rent-seeking behavior. Id. at 11-12. If he is correct, the wealth transfer and efficiency approaches to antitrust are similar or identical.

11 R. BORK, supra note 9, at 91.

12 Bork, supra note 8, at 10. 
as a possible area of congressional concern: "[I]t seems clear the income distribution effects of economic activity should be completely excluded from the determination of the antitrust legality of the activity. It may be sufficient to note that the shift in income distribution does not lessen total wealth. . . ."13

Bork developed his argument through a detailed analysis of the 1890 legislative debates. He pointed to dozens of statements revealing an overriding Congressional concern that trusts and certain other business forms would acquire monopoly (or market) power that would give them the ability to artificially raise prices and restrict output. ${ }^{14}$ Bork wove these quotations into a convincing case that this concern preoccupied Congress. ${ }^{15} \mathrm{He}$ then used modern economic analysis to explain how monopoly power leading to higher prices for consumers can produce a form of economic inefficiency termed "allocative inefficiency." "The explanation of why monopoly pricing produces allocative inefficiency, a reduction in the total wealth of society, is extremely complex. ${ }^{17}$ ) Bork reasoned that since we now

13 R. BoRk, supra note 9, at 111.

14 Bork, supra note 8, passim. For example, Senator Sherman asked that Congress protect the public from trusts that "restrain commerce, turn it from its natural courses, increase the price of articles, and therefore diminish the amount of commerce." 21 Cong. Rec. 2462 (1890). Sherman also stated: "The sole object of such a combination is to make competition impossible. It can control the market, raise or lower prices, as will best promote selfish interests. . . . Its governing motive is to increase the profits of the parties composing it. The law of selfishness, uncontrolled by competition, compels it to disregard the interest of the consumer. . . . [w]hen it embraces the great body of all the corporations engaged in a particular industry in all of the States of the Union, it tends to advance the price to the consumer of any article produced." Id. at 2457.

15 Bork, supra note 8, passim.

16 Id.

17 To raise prices a monopoly reduces output from the competitive level. The goods no longer sold are worth more to would-be purchasers than they would cost society to produce. This foregone production of 
"know" that the "only" harm to "consumer welfare" from higher prices is economic inefficiency, Congressional displeasure with market power can fairly be equated with a concern about economic efficiency. He then presented a smaller, although still significant, number of quotations that manifest a Congressional desire to preserve and enhance corporate productive efficiency. ${ }^{18}$ On the basis of this evidence, Bork concluded that the antitrust laws embody only a concern for "consumer welfare" which he equated with the "maximization of wealth or consumer want satisfaction" 19 and the aggregate efficiency of our economy. ${ }^{20}$

Notice the subtle yet crucial change in terminology. Bork used "consumer welfare" as an Orwellian term of art that has little or nothing to do with the welfare of true consumers! ${ }^{21}$ His desire to maximize "consumer welfare" (which he defines as economic efficiency) carries with it no concern about the wealth extracted from consumers and transferred to firms with market power as a result of the higher prices that arise from cartel or other prohibited behavior. Bork thus defined "consumers" to

goods worth more than their cost is pure social loss and constitutes the "allocative inefficiency" of monopoly. For example, suppose that widgets cost $\$ 1.00$ in a competitive market (their cost of production plus a competitive profit). Suppose a monopolist would sell them for $\$ 2.00$. A potential purchaser who would have been willing to pay up to $\$ 1.50$ will not purchase at the $\$ 2.00$ level. Since a competitive market would have sold them widgets for less than they were worth to him, the monopolist's reduced production has decreased the consumer's satisfaction without producing any countervailing benefits for anyone. This pure loss is termed "allocative inefficiency." For an extended discussion and formal proof that monopoly pricing creates allocative inefficiency, see E. Mansfield, Microeconomics: Theory and Applications 277-92 (4th ed. 1982).

18 Bork, supra note 8, at 26-31.

19 Bork, supra note 8, at 7.

20 R. BORK, supra note 9, at 91.

21 Bork did not invent the term but chose it from the available options. 
include monopolists and cartels. ${ }^{22}$ Antitrust based on his definition of "consumer welfare" makes no distinction between "real" consumers-the purchasers of goods and services-and the firms with market power that raise prices and thereby extract wealth from purchasers. Higher prices to consumers are fine with Bork so long as the monopolist or the cartel produces more efficiently. In fact, the only "consumers" sure to benefit under Bork's regime are monopolists and cartels. ${ }^{23}$

The view that economic efficiency should be the only value that counts in the antitrust analysis was quickly embraced by the entirety of the Chicago School ${ }^{24}$ and many leading "moderate" antitrust analysts as well..$^{25}$ Although this view had been picking up adherents for more than a decade, ${ }^{25}$ it was not really implemented until President Reagan's election.

22 I am indebted to Professor Salop for this and related articulations of this concept.

23 I am indebted to John Kirkwood for this formulation. He observes that in a technical sense "consumer welfare" has increased but that the cartels and monopolists acquire all of this increase. In the classic tradeoff situation "true" consumers gain none of the efficiency benefits, absorb some of the allocative inefficiency losses, and have their surplus extracted by the firms with market power.

24 See sources cited supra note 10 . Of course, some may have adopted the belief that antitrust should be based entirely upon efficiency for reasons having little or nothing to do with Bork's legislative history analysis.

25 See, e.g., 4 P. Areeda \& D. Turner, Antitrust Law: AN ANalysis of Antitrust Principles and Their Application 149, n. 2 (1980).

26 Other milestones in the debate included two symposia: Antitrust Jurisprudence: $A$ Symposium on the Economic, Political and Social Goals of Antitrust Policy, 125 U. PA. L. Rev. 1182 (1977); The Goals of Antitrust: A Dialogue on Policy, 65 Colum. L. Rev. 363 (1965). The 1973 Airlie House Conference was also extremely influential. The efficiency-oriented Chicago view largely triumphed over the social/ political view on all three occasions. 


\section{B. Administrability arguments}

Bork's argument that only an efficiency approach to antitrust is clear and predictable for businesses also won many converts to the efficiency school. Even many who strongly suspected that Congress may have intended the antitrust laws to encompass more had to admit that the social-and-political school of antitrust was extremely difficult to administer. ${ }^{27}$ Bork recently has taken his assertion of superior administrability much further; he has argued that courts cannot include values other than economic efficiency in antitrust analysis "without engaging in a task that is so unconfinedly legislative as to be unconstitutional." 28

As a practical matter Bork admitted that to actually balance the triangles and rectangles that inevitably arose from an efficiency-based analysis was impossible on a case-by-case basis. ${ }^{29}$ But he asserted that only rules based on economic effi-

27 Consider the plight of an honest, aggressive business operating under a "big is bad, small is good" antitrust regime. What mergers can it lawfully undertake? What vertical restraints or pricing decisions can it implement? What are the rules under which we judge its conduct? An efficiency approach carried out through rules, such as clearly designed merger guidelines (but not the relatively unprincipled analysis conducted within the Reagan Administration) would indeed be more workable than a "big is bad, small is good" approach.

28 Bork, The Role of the Courts in Applying Economics, 54 ANTrTRUST L.J. 21, 24 (1985).

29 Bork provided the following summary of what a case-by-case efficiency analysis of a horizontal merger actually would involve:

Passably accurate measurement of the actual situation [including an estimate of efficiencies and deadweight loss] is not even a theoretical possibility; much less is there any hope of arriving at a correct estimate of the hypothetical situation. Consider two of the factors that would have to be known: the demand curve over all possible relevant ranges of output and the marginal cost curve over those same ranges. Only by knowing where marginal cost and demand intersect could one know whether there was a restriction of output and what its size was. Nobody knows these curves. Even the companies involved do not. . . . 
ciency could lead to predictable antitrust decisionmaking. By avoiding the endless and imprecise debates over "how big is too big," "how small is good" or "how much more should consumers pay to prevent bigness and/or preserve smallness," the efficiency view of antitrust with its single quest offered the promise of clarity and predictability. Under this approach the decisionmakers were charged with figuring out, at least as a theoretical matter, the applicable triangles and rectangles, and then with designing rules that would implicitly incorporate them. (Baxter has similarly asserted that "economic efficiency provides the only workable standard from which to derive operational rules and by which the effectiveness of such rules can be judged." ${ }^{30}$ ) Even those whose instincts told them something was wrong with Bork's analysis of the legislative history were understandably dazzled by the economics and found it difficult to answer Bork's administrability arguments.

The administrability claims may have gained more converts than the belief that Congress in 1890 cared only about economic efficiency. Perhaps what took place in the minds of most observers was, in effect, the following: It is clear that in 1890 Congress was concerned with prices increasing as a result of market power, and it is clear that higher prices lead to economic inefficiency. Since economic efficiency is much easier to implement than a "big is bad, small is good" policy, let's choose what seems to be a plausible view of the legislative history since it leads to the most predictable implementation.

(Footnote continued from previous page)

There is a good reason why firms do not know these things, and it is the same reason why they cannot be known through an antitrust trial. The demand curve is not known because it changes continually and because the company is not constantly plotting it by running its prices up and down. The attempt to do so might make a minor contribution to science, but quite a research grant would be required, since the losses incurred in an attempt by a major company might make serious inroads on the resources of even the Ford Foundation.

R. BoRK, supra note 9, at 125-26.

30 Baxter, Responding to the Reaction: The Draftman's View, 71 Calif. L. Rev. 618, 621 (1983) ('Draftman's View'). 
Relative to the then-existing situation, the efficiency standard certainly brought the promise of clarity and predictability. All the decisionmakers had to do was ascertain and balance crisp, clear triangles and rectangles that easily (?) could be predicted in advance by the affected parties. Bork (and others) recognized, moreover, that since rarely in practice could we accurately predict or measure the appropriate efficiencies and inefficiencies, to enhance administrability and predictability we should implement the efficiency approach through rules, not by case-by-case tradeoffs. Thus, for example, Bork ${ }^{31}$ (like Posner) ${ }^{32}$ believes that mergers should be evaluated solely in terms of their efficiency effects, yet would not allow an efficiencies defense. Their approach to mergers giving rise both to allocative inefficiency from higher prices and productive efficiency gains from, for example, economies of scale, would be to set the merger guideline thresholds at a level calculated to allow most productive efficiency gains and prevent most allocative inefficiency losses. They would perform the market power/efficiencies trade-off implicitly, but not have an explicit, case-by-case efficiencies defense. ${ }^{33}$ Their efficiency approach would thus be implemented through relatively clear rules that would optimize business planning and judicial administration.

\section{Efficiency's embrace by the Reagan administration}

It is hardly surprising that President Reagan's first choices to head the antitrust enforcement agencies adopted the efficiency standard. The administration's first Assistant Attorney General for Antitrust, William Baxter, was succinct and clear:

\footnotetext{
31 R. BORK, supra note 9, at 221-22.

32 R. Posner, Antitrust Law: An Economic Perspective 112 (1976).
}

33 R. Bork, supra note 9, at 221-22; R. Posner, supra note 10. 
"The only goal of antitrust is economic efficiency." his successor, Paul McGrath. ${ }^{35}$ This view was also embraced by James C. Miller III, Reagan's first Chairman of the Federal Trade Commission, most spectacularly in the Allied Corp. case. ${ }^{36}$

Allied appears to have been the first antitrust case where the differences between the efficiency and price approaches to antitrust clearly were articulated and were pivotal to the enforcement decision. ${ }^{3}$ Allied involved a merger that would have increased the Herfindahl-Hirschman Index (HHI) in various industrial acid markets by as much as 416 , to a level of as high as 4,026 (figures that normally would suggest a challenge). The FTC economist assigned to the case, Dr. Kenneth Kelly, argued that even if the merger led to a price increase of $10 \%$ in the affected markets (a generous estimate in light of the facts) the merger would be unlikely to lead to any inefficiency since demand for the acids was completely inelastic (i.e., even if price

34 Taylor, A Talk With Antitrust Chief William Baxter, Wall St. J., Mar. 4, 1982, at 28, col. 3. Baxter has also stated: "The fundamental premise of our economic system is that the free market will achieve the greatest possible efficiency in the allocation of resources and thereby yield maximum productivity. . . . One of my principal objectives since joining the Department has been to attempt to ensure that the antitrust laws are enforced and interpreted to achieve that goal." Productivity in the American Economy, 1982: Hearings Before the Subcomm. on Employment and Productivity of the Senate Comm. on Labor and Human Resources, 97th Cong., 2d Sess. 478 (1982) (statement of William F. Baxter, Assistant Atty. Gen., Antitrust Division, U.S. Dep't of Justice); Draftsman's View, supra note 30, at 619-20; Separation of Powers, Prosecutorial Discretion, and the 'Common Law' Nature of Antitrust Law, 60 Texas L. REv. 661, 691-93 (1982).

35 McGrath, Statement of Mr. McGrath, 54 AnrITRusr L.J. 131, 131 (1985).

36 In re Allied Corp., FTC File No. 8110191 (Dec. 8, 1982) ("Allied").

37 This account of Allied is taken from FTC: WATCH, Pub. No. 158, “Cost-Benefit Analysis, Miller Style," 1, 1-5 (Jan. 14, 1983). 
rose by $10 \%$, the quantity sold would not diminish). ${ }^{38}$ Thus, the $10 \%$ price rise would "only" lead to a transfer of wealth from the products' consumers to the industrial acids' producers, a concern that Kelly (following Bork's lead) deemed irrelevant. Moreover, there would be some inefficiency created if the Commission forced the firms to accept a consent order mandating that Allied divest the affected assets. These costs included brokerage fees and private and FTC compliance costs. The Bureau of Economics analysis concluded that since any resulting monetary transfer from the products' consumers to its producers was irrelevant, and since ordering the divestiture would cause inefficiency, the merger should be approved even assuming prices would rise by $10 \% .{ }^{39}$

The issues in Allied can be illustrated by a version of Professor Williamson's famous diagram. ${ }^{40}$ The rise in price from the competitive level $(\mathrm{Pc})$ to the monopoly level $(\mathrm{Pm})$ normally produces both economic inefficiency (triangle I) and transfer of wealth from consumers to the firm with market power (rectangle T). Productive efficiency gains from the merger would lower the firm's costs, from Pc down to the lower dashed line, resulting in the efficiency savings marked $\mathrm{E}$. In the Allied case, area $\mathrm{E}$ was essentially nonexistent-since demand was inelastic within the relevant range the demand curve was vertical. If the wealth transfer from consumers to the merged firm, area $T$, did not count, the productive efficiency benefits from allowing the merger would mandate its approval.

Chairman Miller cast the only vote endorsing the efficiencybased recommendation not to sue. He termed any monopoly overcharges mere "revenue transfers" that should not factor into the enforcement analysis. Miller's decision may have been

38 Id.

39 Kelly's novel analysis was endorsed by Bureau of Economics Director Dr. Robert Tollison. Tollison also would not count the wealth transfer effects of the merger. See 43 Antitrust \& TRAdE REg. Rep. (BNA) 1061 (Dec. 9, 1982).

40 Williamson first presented his analysis in Economies as an Antitrust Defense: The Welfare Tradeoffs, 58 Am. ECON. Rev. 18 (1968). 


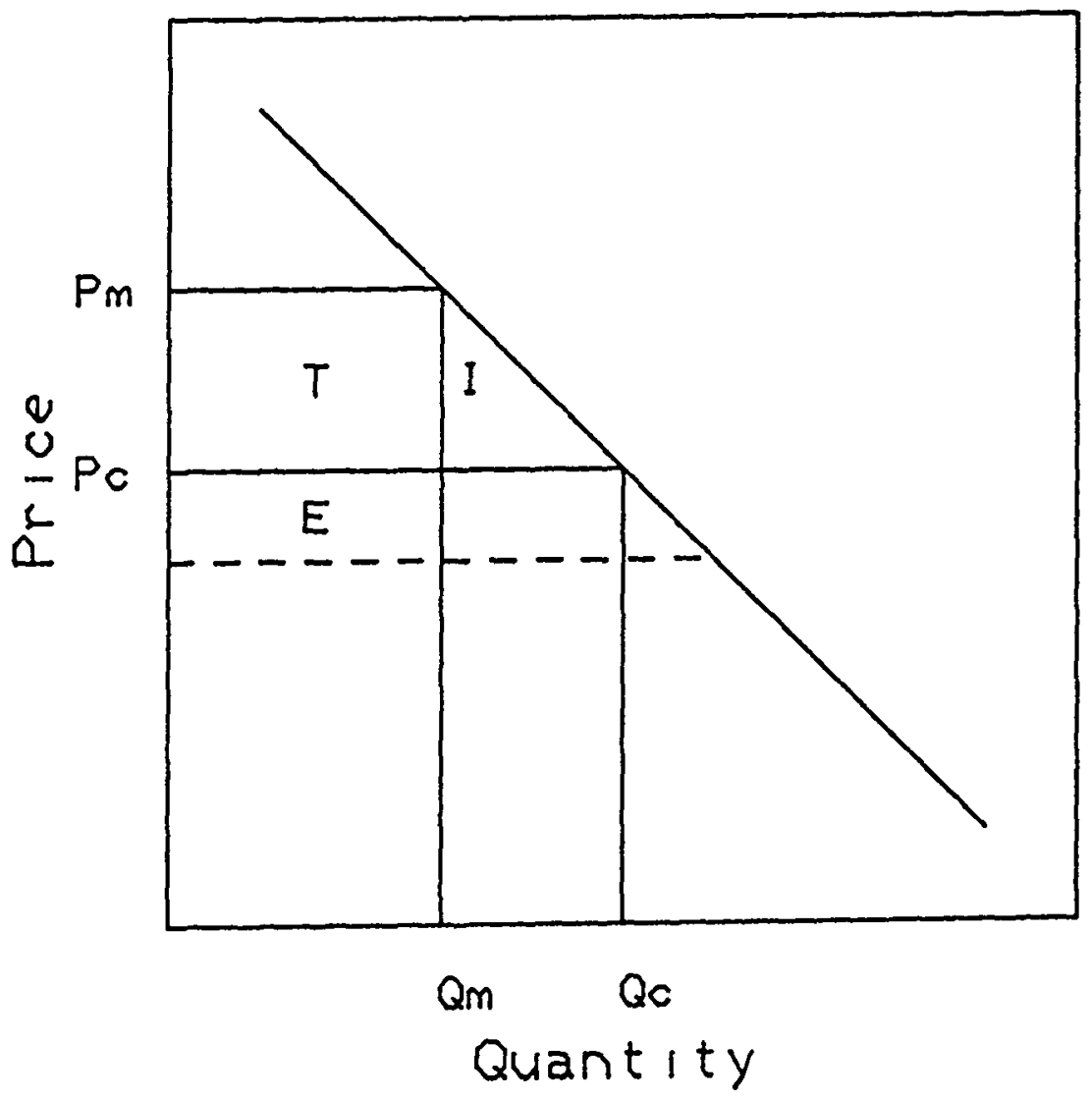

influenced by an article by Professor Timothy Muris (later Miller's Director of the Bureau of Competition) that was precisely on point. Muris argued that only efficiency should count in merger analysis and that a merger producing a net increase in efficiency should be allowed even if it led to significantly higher prices to consumers for a significant period of time..$^{41}$

41 Muris presented a detailed analysis of the legislative history of the Celler-Kefauver Act and argued that Congress meant for mergers to be evaluated solely in efficiency terms. See Muris, The Efficiency Defense Under Section 7 of the Clayton Act, 30 CASE W. Res. L. Rev. $381,393-402$ (1980). For a point-by-point refutation of Muris' analysis, see Lande, supra note 8 , at 132 n.258. 
The Commissioners appointed by President Carter disagreed. They all voted to accept a proposed consent order that included divestiture of the offending assets. They understood clearly the differences between the efficiency and wealth extraction approaches; Commissioner Clanton, joined by Commissioners Bailey and Pertschuk, concluded that "preventing such transfers is one of the goals of the antitrust laws." ${ }^{42}$

Another illustration of the Reagan administration's singlemindedness can be found in the DOJ's 1985 Vertical Restraints Guidelines. ${ }^{43}$ Its section on tying lists a large number of reasons why tying can be procompetitive, but acknowledges no circumstance under which purely private uses of tying, even by a cartel or monopolist, could ever be anticompetitive. ${ }^{44}$ One inevitably leaves this section, the Guidelines' most illogical, wondering why it does not treat tying as per se legal. The explanation for their approach undoubtedly lies in the Department's desire to equate "anticompetitive" with "inefficient"; i.e., their desire to implement the view that the only concern of antitrust is efficiency. The Department's ideological blinders must have caused them to misread or ignore the tying standard set forth in Jefferson Parish Hospital District No. 2 v. Hyde, 466 U.S. 2 (1984) ("Hyde"). ${ }^{45}$ This case can best be explained as condemning certain instances of tying because of wealth transfer effects. ${ }^{46}$

42 FTC: WATCH, supra note 37 , at 3.

43 See U.S. Dep't of Justice, Vertical Distribution Restraints Guidelines, 50 Fed. Reg. 6263 (1985).

44 Id., at Sec. 5 .

45 Hyde involved a contract between a firm of anesthesiologists and a hospital requiring all anesthesiological services for the hospital's patients to be performed by that firm. A competing anesthesiologist tried to obtain privileges to practice at the hospital and was denied on the basis of the contract. For a more detailed discussion see Sims, " 'Monsanto,' 'Hyde' Rulings Put Baxter Slightly Ahead,' Legal Times, Apr. 16, 1984, at 14.

46 For a more complete analysis of tying arrangements using both wealth transfer and efficiency criteria, see R. Lande, "Untangling Tying"' (1988) (unpublished manuscript) (draft). 
Although the majority opinion in Hyde certainly appreciated the value of efficient tying arrangements, ${ }^{47}$ it complained that they also "may be used as a counting device to effect price discrimination, and they may be used to force a full line of products on the customer so as to extract more easily from him a monopoly return on one unique product in the line." ${ }^{348}$ Tying was held to be anticompetitive since it "can increase the social costs of market power by facilitating price discrimination, thereby increasing monopoly profits over what they would be absent the tie ....,49 The court explained how anticompetitive tying can lead to undesirable extractions of wealth by the firm with market power: "Sales of the tied item can be used to measure demand for the tying item; purchasers with greater needs for the tied item make larger purchases and in effect must pay a higher price to obtain the tying item." 50

While five Justices' views can best be explained in terms of wealth transfers, O'Connor's concurring opinion is close to pure Chicago School analysis. This opinion largely ignores the producer-consumer battle, holding that the relevant question is whether tying can ever cause inefficiency. It argues that this rarely occurs ${ }^{51}$ and that even in these unlikely circumstances the inefficiencies from the tie must be balanced against any economic benefits. ${ }^{52}$ It condemned a tying firm's "exploitation of

47 "Basic to the faith that a free economy best promotes the public weal is-[the assumption] that the public, acting through the market's impersonal judgment, shall allocate the Nation's resources." Hyde, at 12 (quoting Times-Picayune Co. v. United States, 345 U.S. 594, 605 (1953)).

48 Hyde at 13 n. 19 (quoting Fortner Enterprises v. United States Steel Corp., 394 U.S. 495, 512 (1968) (dissenting opinion) (footnotes omitted).

49 Hyde at 14 (citing United States Steel v. Fortner Enterprises, 429 U.S. 610,617 (1977).

so Id. at 15 n. 23.

51 Id. at 36-37 (O'Connor, J., concurring).

52 Id. at $40-41$. 
consumers" 33 and the "increase [in] the profit it can extract from . . consumers. . . "s4 The opinion, however, held that even the use of tying to price discriminate is not necessarily undesirable ${ }^{s s}$ and largely focused upon the potential efficiencies and inefficiencies created by tying arrangements. ${ }^{56}$ It cited primarily the work of Bork $^{57}$ and other Chicago School scholars. ${ }^{\text {s8 }}$

Thus, the views of most Reagan administration antitrust enforcers, as well as the views of many Reagan appointed judges, are clear and pure. But while the Supreme Court has become increasingly receptive to the use of economic analysis in antitrust analysis it has never accepted the administration's suggestion to confine antitrust to efficiency considerations.

\section{The Supreme Court's partial embrace of efficiency}

The Supreme Court repeatedly has stated that when it passed the antitrust laws, "Congress was dealing with competition, which it sought to protect, and monopoly, which it sought to prevent."'s9 Yet, the Court rarely has found the need to state precisely what "competition" embraces. While there are older

\footnotetext{
53 Id. at 35.

$54 \quad$ Id. at 36.

$55 \quad$ Id. at 36 n. 4.

56 "A tie-in should be condemned only when its anticompetitive impact outweighs its contribution to efficiency." Id. at 42.

57 Id. at 36.

58 For example, O'Connor cites Landes \& Posner, Market Power in Antitrust Cases, 94 HARv. L. Rev. 937, 954 (1981) at 37 n. 7, and Bowman, Tying Arrangements and the Leverage Problem, 67 YALE L.J. 19, 21-23 (1957) at 39 n. 9.
}

59 Standard Oil v. Federal Trade Commission, 340 U.S. 231, 248-49 (1951) (quoting $A$. E. Staley $M f g$. Co. v. Federal Trade Commission, 135 F.2d 453, 455 (7th Cir. 1943). 
cases that are relatively explicit, ${ }^{60}$ only since the landmark opinion in Continental T.V. Inc. v. GTE Sylvania, 433 U.S. 36 (1977) has a specific concern with efficiency consistently been at the forefront of Supreme Court antitrust analysis. ${ }^{61}$ This case was followed shortly by Broadcast Music Inc. $v$. Columbia Broadcasting System Inc., 441 U.S. 1 (1978) ('BMI') and others. ${ }^{62}$ Moreover, in Reiter v. Sonotone Corp., 442 U.S. 330

60 For example, in Northern Pacific Ry. v. United States, 356 U.S. 1, 4 (1958), the Court stated:

The Sherman Act ... rests on the premise that the unrestrained interaction of competitive forces will yield the best allocation of our economic resources, the lowest prices, the highest quality and the greatest material progress, while at the same time providing an environment conducive to the preservation of our democratic political and social institutions.

See also United States v. E. I. Du Pont de Nemours Co., 351 U.S. 377, 386 (1956) ("A considerable size is often essential for efficient operation in research, manufacture and distribution'); Connell Constr. Co. $v$. Plumbers \& Steamfitters Local 100, 421 U.S. 616, 623 (1975) (" [C]ompetition based on efficiency is a positive value that the antitrust laws strive to protect").

61 In Sylvania the Court changed the standard of analysis for nonprice vertical restraints from per se illegality to the rule of reason largely because of the efficiencies they generate. The Court noted that while vertical restrictions can reduce competition in a number of ways:

Vertical restrictions promote interbrand competition by allowing the manufacturer to achieve certain efficiencies in the distribution of his products. These "redeeming virtues" are implicit in every decision sustaining vertical restrictions under the rule of reason. Economists have identified a number of ways in which manufacturers can use such restrictions to compete more effectively against other manufacturers. Id. at 54-55.

$62 B M I$ justified a blanket licensing provision because it "reduces cost" (id. at 21), would "serve a market need" (id. at 17 n. 27), obviates certain transaction costs (id.), and because "a bulk license of some type is a necessary consequence of the integration necessary to achieve these efficiencies, and a necessary consequence of an aggregate license is that its price must be established." Id. The Court inquired whether the purpose of the practice was: 
(1979), Chief Justice Burger stated that the Sherman Act's legislative debates "suggest that Congress designed the Sherman Act as a 'consumer welfare prescription'" (citing R. BORK, THE ANTITRUST PARADOX 66 (1978))). ${ }^{63}$ Of course, Bork has asserted that the "consumer welfare prescription" embodied in the antitrust laws is limited to a concern with economic efficiency ${ }^{64}$

As the Court's subsequent discussion makes clear, however, it almost certainly was unaware that "consumer welfare," as Bork defines it, has little or nothing to do with the welfare of consumers. Moreover, Reiter implies that the antitrust laws contain wealth transfer goals and a strong preference for consumers:

It is in the sound commercial interests of the retail purchasers of goods and services to obtain the lowest price possible within the framework of our competitive private enterprise system. . . . Here,

(Footnote continued from previous page)

to threaten the proper operation of our predominantly freemarket economy - that is, whether the practice facially appears to be one that would always or almost always tend to restrict competition and decrease output, or instead one designed to "increase economic efficiency and render markets more, rather than less, competitive" (citing United States v. United States Gypsum Co., 438 U.S. 422, 441 n. 16 (1978). Id. at 19-20.

In National Soc'y of Professional Eng'rs v. United States, 435 U.S. 679 (1978), the Court struck an anticompetitive association canon of ethics because "[ $t]$ he Sherman Act reflects a legislative judgment that ultimately competition will produce not only lower prices, but also better goods and services." Id. at 695. In City of Lafayette v. Louisiana Power \& Light Co., 435 U.S. 389, 408 (1978), the Court commented upon "the potential of serious distortion of the rational and efficient allocation of resources, and the efficiency of free markets which the regime of competition embodied in the antitrust laws is thought to engender." The Court in United States Gypsum, 438 U.S. 422, 441 n. 16 (1978), observed that a certain exchange of information among competitors "does not invariably have anticompetitive effects; indeed such practices can in certain circumstances increase economic efficiency and render markets more, rather than less, competitive."

442 U.S. at 343. 
where petitioner alleges a wrongful deprivation policy of her money because the price of the hearing aid she bought was artificially inflated by reason of respondents' anticompetitive conduct, she has alleged an injury in her 'property.' . . . [The treble-damages remedy was passed] as a means of protecting consumers from overcharges resulting from price fixing. ${ }^{.5}$

Justice O'Connor's concurring opinion in Hyde demonstrates that the view that antitrust should only be concerned with economic efficiency may have as many as four Supreme Court votes. But, for the present, a majority appears reluctant to restrict antitrust to efficiency. This cursory overview of recent cases has shown a trend from a concern with competition to a concern with the efficiency that results from competition. But the Chicagoist victory is not complete.

\section{The "counterrevolution" begins}

\section{A. Analyzing the legislative history correctly}

Many older cases imply that one purpose of the antitrust laws is to prevent the formation of market power that, when exercised, transfers wealth from consumers to firms with market power. ${ }^{66}$ Yet, although many doubted Bork's legislative history

65442 U.S. at 339-43. This language accords with statements from earlier cases implying wealth transfer principles. For example, in Albrecht v. Herald Co., 390 U.S. 145, 153 (1967), the Court implied that it was an antitrust goal to "protect the public from price gouging by dealers who had monopoly power. . . ." In Buckley v. Valeo, 424 U.S. 1, 263 (1976), Justice White, in dicta in a separate opinion concurring in part and dissenting in part, stated that "[t]he antitrust laws are aimed at preventing monopoly profits and price fixing, which gouge the consumer."

66 See, e.g., Hanover Shoe v. United Shoe Machine, 392 U.S. 481, 489 (1967); Brunswick Corp. v. Pueblo Bowl-O-Mat, Inc., 429 U.S. 477, 486 (1976); United States v. McKesson \& Robbins, Inc., 351 U.S. 305, 309 n. 9 (1956) (condemned an "intent to gouge consumers"); Associated General Contractors v. Carpenters, 459 U.S. 519, 538 (1983) ("the Sherman Act was enacted to assure consumers the benefits of price competition ....'). 
analysis, ${ }^{67}$ well over a decade passed before Bork's conclusions were challenged in detail. ${ }^{68}$

Bork had correctly noted that the Sherman Act's legislative history is replete with concern over the higher prices facing consumers as a result of monopoly pricing. But he was mistaken that Congressional concern fairly can be equated to a desire to avoid economic inefficiency. None of the quotations Bork presents suggest that Congress was even aware that supracompetitive prices lead to economic efficiency. ${ }^{69}$ Even leading economists of the day had only a tenuous understanding of this concept $^{70}$ and, as conservative Nobel Laurate George Stigler reminds us, no economist had any significant effect on the Sherman Act's passage. ${ }^{11}$ Not surprisingly, Bork's hundreds of

67 See, e.g., Scherer, The Posnerian Harvest: Separating Wheat From Chaff, 86 YALE L.J. 974, 976-79 (1977) (using common sense to conclude that Congress must have been more concerned about wealth transfers than efficiency).

68 See Lande, supra note 8. The legislative history material in this article has been taken from this source.

69 See Bork, supra note 8 , passim.

70 Scherer observed that although a few nineteenth century economists discussed what we today term allocative efficiency insofar as it related to taxation and the government regulation of public utilities: "The notion of a 'deadweight welfare-loss triangle' entered the mainstream of Anglo-American economics in the first edition [1890] of Marshall's Principles [citation omitted]." Scherer, supra note 67, at 977 n. 20. Moreover, the first rigorous discussion of allocative efficiency did not appear until 1938. Hotelling, The General Welfare in Relation to Problems of Taxation and of Railway and Utility Rates, 6 EcoNomETRICA 242 (1938). Even this relatively modern analysis did not discuss the antitrust implications of allocative inefficiency.

71 "A careful student of the history of economics would have searched long and hard, on July 2, 1890, the day the Sherman Art was signed by President Harrison, for any economist who had ever recommended the policy of activity combating collusion or monopolization in the economy at large." Stigler, The Economists and the Problem of Monopoly, 72 Am. Econ. REv. 1, 3 (1982). Professor Hofstadter 
citations to the 1890 debates fail to contain evidence that even a single Congressman knew that monopoly pricing is inefficient. Put simply, Congress did not condemn the trusts for a lack of efficiency.

Congress was well aware, however, that higher prices transfer wealth from consumers to firms with market power. The debates strongly suggest that Congress condemned trusts and monopolies for exactly this reason. ${ }^{72}$ For example, Senator Sherman termed monopolistic overcharges "extortion which makes the people poor," and "extorted wealth." referred to the overcharges as "robbery." Heard declared that the trusts, "without rendering the slightest equivalent," have "stolen untold millions from the people." Congressman Wilson complained that a particular trust "robs the farmer on the one hand and the consumer on the other." "76 Representative Fithian declared that the trusts were "impoverishing" the people through "robbery." "7 Senator Hoar declared that monopolistic pricing was "a transaction the direct purpose of which is to extort from the community . . . wealth which

observed that " $[t]$ he Sherman Act was framed and debated in the preexpert era, when economists as a professional group were not directly consulted by legislators. But even if they had been, they would have given mixed and uncertain advice." R. Hofstadter, The Paranoid Style in American Politics and Other Essays 199-200 (1965).

72 This paper only analyzes the legislative history of the Sherman Act. For a similar analysis of the legislative history of the Clayton Act, Federal Trade Commission Act, and Celler-Kefauver Act, demonstrating that these laws' framers cared more about wealth transfers than efficiency, see Lande, supra note 8.

7321 Cong. Rec. 2461 (1890).

74 Id. at 2614.

75 Id. at 4101.

76 Id. at 4098.

77 Id. at 4103 (Fifthian was reading, with apparent approval, a letter from a constituent). 
ought to be generally diffused over the whole community." 78 Senator George complained: "They aggregate to themselves great enormous wealth by extortion which makes the people poor." "79

These value-laden condemnations of the wealth extraction effects of monopoly pricing show a much broader concern than economic efficiency. A fair reading of the Sherman Act's legislative history reveals that it is largely a consumer protection statute. Congress' primary reason for passing the antitrust laws was to prevent consumers from paying more than the competitive level for their goods and services. Bork tried to make the stockholders of monopolies and cartels into honorary consumers; the consumers that Congress wanted to protect included only purchasers of goods and services. ${ }^{80}$

\section{B. Triangles and rectangles disentangled}

Despite the common sense that truly underlay Congressional intent it is not difficult to understand how Bork's story gained such widespread acceptance. Perhaps the most important reason was his clever but deceptive selection of his key term, "consumer welfare," as the lodestar of antitrust. Few people realize how he counterintuitively defined it to exclude a concern with the welfare of ordinary consumers. Bork succeeded in promot-

$78 \quad I d$. at 2728.

79 Id. at 1768. Senator George continued: "Then making this extorted wealth the means of further extortion from their unfortunate victims, the people of the United States, they pursue unmolested, unrestrained by law . . . . [They] have extorted their ill-gotten gains from the poor and then used the money thus obtained to complete the ruin of the people." Id. Senator George complained that consumers were being robbed. $I d$. at 3150 . He also complained that the trusts were able to "fleece and rob the people." Id.

80 This article asserts that the wealth transfer standard should govern antitrust because Congress has so ordered, not because it is the superior approach. That is the subject of another article that the author is working on. 
ing this interpretation largely because the subject is extremely complex; few understand that monopoly prices lead to both allocative inefficiency and a transfer of wealth from consumers to the monopolist. As Bork translated legislative intent into triangles and rectangles and then back to an appealing term like "consumer welfare," few discovered what he had really done. ${ }^{81}$ Even the Supreme Court appears to have been confused. ${ }^{82}$ Perhaps the clearest illustration of the complexity of the issues is that Bork, in his landmark legislative history analysis, twice appeared to suggest that the antitrust laws are concerned with wealth transfers from consumers to firms with market power! ${ }^{83}$

81 I have argued elsewhere that Bork's interpretations of Congressional intent in his original area of specialization demonstrate that he is a judicial activist for his ideological causes. Contrary to his protestations and those of his champions, Bork selectively interprets Congressional will to suit his own agenda; he does not defer to a Congress that had different goals. Bork saves his "strict constructionist" view of a judge's role for instances when this posture is consistent with his preferred ends. In other cases he finds a way to reach the result demanded by his ideology and denounces contrary conclusions as "unconstitutional." See Lande, Just Where Does Judge Bork Stand?-An Anti-Antitrust Activist? NaT'L L.J., Sept. 7, 1987, at 13 col. 4. Most of this article's discussions of Bork's views are taken from this piece or from Lande, supra note 8.

82 Recall the discussion of Reiter, supra Section I(D).

83 Bork observed that the argument in Congress for a rule against monopolistic mergers "derived in large measure from a desire to protect consumers from monopoly extortion. . . . Where producer and consumer welfare might come into conflict . . . Congress chose consumer welfare as decisive." Bork, supra note 8 , at 11 . A concern with "monopoly extortion" and "consumer," as opposed to "producer" welfare would seem to be identical to a concern with the income distribution effects of economic activity that Bork repeatedly said were to have nothing to do with antitrust.

In addition, Bork discussed $\S 1$ of Sherman's bill in a way that indicated his belief that Congress employed price, not efficiency, as its standard. "[T]hat bill declared illegal two classes of arrangements, contracts, agreements, trusts or combinations: (1) those made with a view, or which tend, to prevent full and free competition, and (2) those designed, or which tend, to advance the cost to consumer of articles of commerce." Id. at 15 (citation omitted) (emphasis added). Bork ana- 


\section{2 : The antitrust bulletin}

If even Bork can use the concepts imprecisely it is not surprising so many were confused.

\section{Administrability counterarguments}

The efficiency approach, if carried out through clearly designed rules (such as well specified merger guidelines rather than the ad hoc case-by-case analysis used during much of the Reagan administration), would indeed prove relatively more workable than a "big is bad, small is good" approach. But an efficiency orientation is certainly no easier to administer and no more predictable than a price (that is, a wealth transfer) approach. Under each the required quantities-a prediction of both market power and efficiencies-are virtually identical. From a theoretical perspective both involve ascertaining virtually the same triangles and rectangles. ${ }^{84}$ From a practical perspective, both are often unworkable on a case-by-case basis since the required quantities are generally unknowable. ${ }^{85}$ Both necessitate implementation through general presumptions or rules. But the two approaches lead to very different rules. ${ }^{86}$

lyzed this language in the following manner. "Sherman employed these two criteria of illegality in every measure he presented to the Senate. The first test, which subjects all firms to market forces, is hardly a means of preserving social values that consumers are not willing to pay for. It can be reconciled only with a consumer-welfare policy. The second test is even more explicit. The touchstone of illegality is raising prices to consumers. There were no exceptions. Sherman wanted the courts not merely to be influenced by the consumer interest but to be controlled completely by it." Id. at 15-16 (citation omitted) (emphasis added).

84 The "price to consumers" standard actually requires less information and is more workable. See A. Fisher, F. Johnson \& R. Lande, Mergers, Market Power and Property Rights: When Will Efficiencies Prevent Price Increases? (September, 1985) (unpublished manuscript) (FTC Working Paper No. 130).

85 R. Bork, supra note 9, at 125-26.

86 Bork wrote that mergers should be evaluated solely in terms of efficiency effects. He would evaluate mergers that gave rise both to allo- 
Consider two differences that would arise if a new set of federal antitrust enforcers attempted to use a supposedly "unconstitutional" antitrust law to prevent consumers from being forced to pay monopoly extortion. ${ }^{87}$ Both would lead to significantly more aggressive antitrust enforcement.

The first would be the undramatic lowering of the DOJ Merger Guidelines' numerical threshold levels. For illustration, reconsider the diagram and the Williamsonian approach to merger enforcement discussed in Section $\mathrm{I}(\mathrm{C})$, supra. Suppose we formulate merger guidelines based only on the efficiency criteria, and suppose we believe that the point where the inefficiencies from most mergers outweigh their efficiency benefits occurs on the average when a merger produces an $\mathrm{HHI}$ increase of 200 to a level of 2000 (figures closer to the current "practical" levels used by the Department of Justice, despite the nominally lower levels written into the 1984 Merger Guidelines). Now, consider the effect of also incorporating the wealth transfer effects of the merger. As the diagram illustrates, these effects are almost always large relative to the accompanying inefficiency effects. ${ }^{88}$ Incorporation of Congress' intent to count these transfers would produce significantly lower merger guidelines than would the efficiency approach. ${ }^{89}$ But administrability would not be affected.

More dramatically, consider a merger that produced an efficient monopolist that would raise prices significantly (recall the

cative inefficiency (from higher price) and productive efficiency gains (from, for example, economies of scale) by setting the thresholds of illegality in the merger guidelines high enough to allow most productive efficiency gains and prevent most allocative inefficiency losses. But he would not allow a generalized efficiencies defense. R. BORK, supra note 9, at 221-22.

87 For additional differences, see Sims \& Lande, The End of Antitrust-or a New Beginning? 31 ANTITRUst BulL. 301, 316-18 (1986).

88 See discussion infra at Section III(B).

89 The particulars of the tradeoff calculations are extremely complex. See Fisher, Lande \& Vandaele, Afterword: Could a Merger Lead to Both a Monopoly and a Lower Price?, 71 CALIF. L. Rev. 1697 (1983). 
Allied case, supra, Section I(C)). The efficiency approach would ask only whether the merger produced (net) efficiencies. If so, one would approve the merger even though all the efficiency savings from the merger would accrue to the monopolist while consumers would be forced to pay significantly higher prices. By contrast, an "unconstitutional" merger policy truly based upon Congressional intent would block such mergers. A "wealth transfer" or "price to consumer" approach to merger enforcement would ask a different question: is the merger likely to lead to significantly higher prices for consumers? If the answer is "yes" the merger would be blocked, even though this would prevent the formation of an efficient monopoly. Congress cared more about protecting consumers from monopoly extortion than obtaining the "benefits" of allowing efficient monopolies. Again, the result would be different, but it would be at least equally administrable.

Ironically, while the efficiency school's founders' concern for predictability and objective administrability was admirable, some of their disciples in the Reagan administration appear not to have fully grasped their teachers' message. Perhaps the disciples focused too much on the technical aspects of Chicago School economics at the expense of broader Chicago School philosophical concerns. For example, the 1984 Merger Guidelines in effect announce that the Department will listen to any type of efficiency claim and give it any weight the Department deems appropriate. ${ }^{0}$ This approach to merger enforcement inflicts administrability and business planning havoc comparable to that committed by the social and political approach the Chicagoists denounce on predictability grounds. Thus, even though the efficiency school gained many adherents because of its promise of superior administration, its practical implementation cannot be shown to be superior.

90 U.S. Dep't of Justice Merger Guidelines (1984), 2 TRADE REG. REP. (CCH) $\{4494.103$ at 4.135. For other examples of how the current Merger Guidelines do not embody clear rules, see Sims \& Lande, "DOJ Adds Revisionist Dollop to '82 Merger Guidelines,' Legal Times, June 25,1984 at 15 , col. 1 . 


\section{The start of efficiency's decline}

\section{A. The "counterrevolution" gains momentum}

It is not surprising that many established moderate and liberal antitrust scholars quickly endorsed the idea that an important goal of antitrust is to protect consumers from monopoly overcharges. It would have been startling if scholars such as Professors Adams, Brodley, Flynn, Fox, Pitofsky, Schwartz or L. Sullivan rejected the idea. Of perhaps greater significance has been this view's adoption by antitrust's most influential "centrist" academic and its embrace by an outstanding group of relatively young scholars who comprise a large portion of the emerging generation of influential antitrust academics.

In 1980 Professor Areeda appeared to endorse the view that economic efficiency should be the only factor in antitrust analysis. ${ }^{91}$ He stated more recently that a broader perspective was appropriate, observing that even if a hypothetical, perfectly discriminating cartel caused no inefficiency:

[It] is taking from some people and giving to the other people more than competition would. I regard this as an anticompetitive distortion. "Consumer welfare" embraces what individual consumers are entitled to expect from a competitive economy. If the efficiency extremists insist that only their definition of consumer welfare is recognized by economists, we would answer that ours is clearly recognized by the statutes. The legislative history of the Sherman Act is not clear on much but it is clear on this. ${ }^{92}$

Many younger scholars concur.93 Professor Hovenkamp, a self-described Chicago School "fellow traveler" for some

91 See 4 P. Areeda \& D. Turner, Antitrust Law: An Analysis of Principles and Their Application 149 n. 2 (1980).

92 Areeda, Introduction to Antitrust Economics, 52 ANTrTrust L.J. 523, 536 (1983). Since Areeda testified in favor of Bork's nomination to the Supreme Court it would be interesting to know whether Bork was one of the "efficiency extremists" to whom Areeda referred.

93 "Younger" is used as a relative term to include open-minded thinkers even if they have some gray hair. 
time, ${ }^{*}$ now explicitly embraces wealth transfers as an important concern of antitrust..$^{95}$ Professors Campbell,,$^{96}$ Jorde, ${ }^{97}$ Kaplow, ${ }^{98}$ Kovacic, ${ }^{99}$ Krattenmaker, ${ }^{100}$ Ross, ${ }^{101}$ Salop, ${ }^{102}$ T. Sullivan, ${ }^{103}$

94 Hovenkamp, Antitrust Policy After Chicago, 84 Mich. L. Rev. 213 (1985).

95 Hovenkamp recently addressed the issue of the legislative intent behind the antitrust laws and concluded that efficiency was not the primary concern of the Clayton Act, the Robinson-Patman Act or the Celler-Kefauver Act. Id. at 250. He termed Bork's Sherman Act legislative history analysis the strongest argument in favor of efficiency but concluded that 'Bork's work has been called into question by subsequent scholarship showing that . . . Congress had no real concept of efficiency and was really concerned with protecting consumers from unfavorable wealth transfers." Id.

96 See Campbell, Has Economics Rationalized Antitrust?, 52 ANTITRUST L.J. 607, 617 (1983) (focusing largely upon the Robinson-Patman Act).

97 See, e.g., Harris \& Jorde, Antitrust Market Definition: An Integrated Approach, 72 CALIF. L. Rev. 1, 14-16 (1984).

98 Kaplow, The Accuracy of Traditional Market Power Analysis and a Direct Adjustment Alternative, 95 HARv. L. REv. 1817, 1822-23 (1982).

99 See Kovacic's article in this volume.

100 Krattenmaker \& Salop, An Antitrust Analysis of Exclusionary Behavior, 94 YALE L.J. 209, 279-80 (1986).

101 See S. Ross, Sports Broadcasting, Antitrust, and Public Policy, Testimony Before the Subcomm. on Antitrust, Monopolies and Business Rights of the Comm. on the Judiciary, 100th Cong., 2d Sess. 2 (Oct. 6, 1987).

102 See Krattenmaker \& Salop, supra note 100.

103 Sullivan, The Economic Jurisprudence of the Burger Court's Antitrust Policy: The First Thirteen Years, 58 Notre Dame L. Rev. 1 (1982). 
Wiley ${ }^{104}$ and many others have come to similar conclusions. Unlike the earlier list of more established scholars, each views antitrust questions mostly or entirely in economic terms. But their economics embraces more than efficiency.

The State Attorneys General, rapidly becoming an important factor in the antitrust world, agree. They vigorously endorsed wealth transfers as the primary concern of merger policy in their 1987 Horizontal Merger Guidelines. ${ }^{105}$ And, although courts still generally do not focus upon the differences between the approaches, some are beginning to recognize that Bork's definition of "consumer welfare" is too narrow" ${ }^{106}$ or is in doubt. ${ }^{107}$

104 Wiley has expressed this view in several articles. See, e.g., Revision and Apology in Antitrust Federalism, 96 Y ALE L.J. 1277, 1283 n. 32 (1987); Antitrust and Core Theory, 54 U. ChI. L. Rev. 556, 587 n. 109 (1987); A Capture Theory of Antitrust Federalism, 99 HaRv. L. Rev. 713, 749 n. 165 (1986); 'After Chicago' An Exaggerated Demise?," 6 Duke L.J. 1006, 1011 n. 38 (1986).

105 "When a firm or firms exercise market power by profitably maintaining prices above competitive levels for a significant period of time a transfer of wealth from consumers to those firms occurs. This transfer of wealth is the major evil sought to be addressed by section 7." Horizontal Merger Guidelines of the National Association of Attorneys General, 52 Special Supp. Antitrust \& Trade Reg. (BNA) No. 1306, at S-4 (March 12, 1987) (footnotes omitted).

106 See Judge Wald's concurrence to Judge Bork's opinion in Rothery Storage \& Van Co. v. Atlas Van Lines, 792 F.2d 210, 231, n. 3 (D.C. Cir. 1986) ("Even if one thinks that the Court intended to exclude all other considerations, the phrase 'consumer welfare' surely includes more than simple economic efficiency"). The Court in Inglis \& Sons Baking Co. v. ITT Continental Baking Co., 668 F.2d 1014, 1032 (9th Cir. 1981), cert. denied, 459 U.S. 825 (1982), shrewdly observed:

Most commentators who have attempted to develop economic tests of predatory pricing have assumed that the goal of these tests should be the efficient allocation of society's resources, or, in the language of welfare economics, the improvement of allocative efficiency. . . . The relevance of the economic tests so developed, however, must then depend in large part on whether allocative efficiency is a primary goal of the antitrust laws. . . . [In our opinion] the search for allocative efficiency may lead one to accept conduct that is plainly anticompetitive.

Paschall v. Kansas City Star Co., 727 F.2d 692, 701, n. 9 (1984). 


\section{B. The Reagan administration's no longer solid front}

Many Reagan Administration antitrust officials remain faithful to Baxter and Miller's legacy. ${ }^{108}$ For example, the current Assistant Attorney General for Antitrust, Charles F. Rule, confidently asserts that the only goal of the antitrust laws is to maximize economic efficiency. ${ }^{109} \mathrm{He}$ affirmatively declines to enforce the antitrust laws in a manner that favors consumers over cartels, noting: "[I]t is not necessarily clear who-the consumer or the producer-is more worthy of the surplus generated by a particular transaction." "all too often" those not sharing his beliefs are engaging in "demagoguery" "' and asserts that including values other than efficiency in antitrust "is a prescription for tyranny."112

Federal Trade Commission Chairman Daniel Oliver uses equally strident language. ${ }^{113}$ But Oliver's statements about the

108 FTC Commissioner Calvani, for example, strongly maintains that the only proper concern of antitrust is economic efficiency. See Calvani, Consumer Welfare Is Prime Objective of Antitrust, Legal Times, Dec. 24/31, 1984, at 14 col. 1.

109 C. Rule, Remarks at the 21st New England Antitrust Conference, Antitrust, Consumers and Small Business, Cambridge, MA, passim, especially at pp. 3-6, 8-9 (Nov. 13, 1987).

$110 \quad I d$. at $4-5$.
$111 \quad I d$. at 1.
$112 \quad I d$. at 9.

113 In a recent interview Chairman Oliver stated that under the Administration's approach to evaluating mergers and acquisitions "the crucial question is whether such transactions will substantially lessen competition-and hence injure consumers-by increasing price or reducing output." Statement of Chairman Oliver, 57 ANTIrRUST L.J. 235, 237 (1988). Oliver then denounced "counter-revolutionaries" (id. at 241) who advocate "nonlearning-antitrust laws as a mechanism to prevent wealth transfers." Id. at 242 (quoting Professor Rose with approval) (citation omitted). Oliver also denounced " $[t]$ he confiscatory, redistributive, and wealth-destructive policies of yesterday's [antitrust enforcement]. Id. at 243. 
subject contradict one another; either he misunderstands the price/efficiency distinction or deliberately confuses it in an attempt to make it appear that he cares about protecting consumers from monopoly extortion. ${ }^{14}$

Further evidence of a "counterrevolution" is, however, provided by the Reagan Administration's no longer solid support for a pure efficiency model. This is prominently evidenced by the Administration's proposed Merger Modernization Act of 1986. The Administration proposed changing Section 7's ban against certain mergers the effect of which may be "substantially to lessen competition, or to tend to create a monopoly," to a requirement that forbidden mergers "increase the ability to exercise market power." 115 The Bill adds: "For the purposes of this section, the ability to exercise market power is defined as the ability of one or more firms profitably to maintain prices above competitive levels for a significant period of time."116 This is virtually the equivalent of a wealth transfer standard since any merger that leads to higher prices to consumers will be blocked, regardless of whether it produces net efficiencies. Effi-

\section{(Footnote continued from previous page)}

Oliver has contradicted himself. Merger enforcement aimed at preventing higher prices to consumers does prevent wealth transfers from consumers to firms with market power. Merger enforcement that ignored wealth transfer concerns would permit higher prices to consumers so long as the resulting monopoly was efficient. Oliver cannot both be in favor of protecting consumers from injury caused by higher prices and also be against preventing wealth transfers from consumers to firms with market power.

Perhaps Chairman Oliver doesn't realize that it is the cartels and monopolies (not the antitrust laws) that are engaging in the redistribution of wealth. The antitrust laws are supposed to be used to prevent cartels and monopolies from using their market power to extract consumers' wealth. This wealth is the property of consumers because Congress gave consumers the right to purchase competitively priced goods.

114 Id.

115 See S. 2160, 99th Cong., 2d Sess., \& 2(a) (1986). The Bill would make many other changes, including a new standard of proof.

116 Id. at $\S 2(\mathrm{~d})$. 
ciencies "deriving from the acquisition" are relevant only insofar as they affect the firm's ability to increase prices. ${ }^{117}$

It is, of course, unclear the extent to which the Administration's merger proposal represented its preferred solution, ${ }^{118}$ a concession to political reality, ${ }^{119}$ or a recognition that in many circumstances an efficiency standard will provide less clarity for

117 Id. Interestingly, both the 1982 and 1984 Merger Guidelines are ambiguous as to whether more than economic efficiency will count in the Department's merger analysis, merely noting that a merger can cause both: "[T]he result [of market power] is a transfer of wealth from buyers to sellers and a misallocation of resources." U.S. Dep't of Justice Merger Guidelines 1982, 2 TrADE REG. REP. (CCH) I 4501 (footnote omitted); 1984 Merger Guidelines, supra note 90 at $\{4491$.

118 A strong supporter of such legislation, former Assistant Attorney General Douglas H. Ginsburg, noted:

Under the Merger Modernization Act [of 1986], an efficiencyenhancing but price-increasing merger could be interdicted. As a matter of enforcement discretion, however, I would have been unlikely, as Assistant Attorney General, to have opposed a merger that was demonstrably efficient. At the same time, I hasten to point out, however, that I did not find the efficiencies claim persuasive in any of the admittedly few merger reviews where the point was argued. . . . [However,] [p]articularly in view of the infrequency with which efficiency showings can convincingly be made on behalf of a proposed merger, a pricedriven standard for mergers would do more to avoid lost efficiencies through over-enforcement (of the Von's, Brown, or $P N B$ sort) than could possibly be lost by the occasional blocking of a merger that would be both price and efficiency enhancing.

Letter from Judge Douglas H. Ginsburg to Robert H. Lande (Feb. 3, 1988). Ginsburg cautions that one carefully should observe the distinction "between the interpretation of present law and a proposal for change, such as the Merger Modernization Act." Id.

119 Neither the Antitrust Division nor the FTC has ever publicly stated that it refused to challenge a merger, despite the expectation of higher prices, because of anticipated efficiencies. They are not so foolish-imagine the reaction in Congress if either the FTC or the Antitrust Division announced it would not challenge a merger likely to lead to significantly higher prices for consumers because the resulting monopoly would be efficient! 
businesses and will be harder to administer. ${ }^{120}$ But it matters little.

There is even an indication that Judge Easterbrook may be starting to mellow. A Reagan appointee, Judge Easterbrook has long been a respected advisor and mentor to many Reagan Administration antitrust officials and one of the most influential members of antitrust's efficiency school. ${ }^{121} \mathrm{He}$ recently wrote that when Congress passed the Sherman Act:

The choice they saw was between leaving consumers at the mercy of trusts and authorizing the judges to protect consumers. However you slice the legislative history, the dominant theme is the protection of consumers from overcharges. ${ }^{12}$

120 For example, Posner admits that in certain circumstances efficiency is too difficult to measure. He advocates instead using an output test. See, e.g., Posner, The Next Step in the Antitrust Treatment of Restricted Distribution: Per Se Legality, 48 U. ChIcAco L. REv. 6, 21 (1981). Since restricted output causes supracompetitive prices, an output standard is very similar to a proscription against practices that lead to higher prices for consumers.

There are, of course, some differences between an output standard and a wealth transfer standard. In cases where output is completely inelastic, such as in Allied, discussed supra, Section I(C), the two standards would lead to different results. In addition, Posner would not appear to condemn Areeda's hypothetical, perfectly price-discriminating cartel since such a cartel would not reduce output.

An output standard also was recently proposed by the Director of the FTC's Office of Policy Development, Nolan Clark. He argues that the Sherman Act's proscription against certain practices 'in restraint of trade" (26 Stat. 209 (1890) (current version at 15 U.S.C. 1 (1976)) was meant to constitute a ban against practices that restrain output (since trade is only restrained when output decreases). Clark contrasts his proposal with an efficiency standard and explains why reduced output and reduced efficiency are not identical. See Clark, Antitrust Comes Full Circle: The Return to the Cartelization Standard, 38 VAND. L. REv. $1125,1168-70$ (1985).

121 See, e.g., Easterbrook, The Limits of Antitrust, 63 Texas L. Rev. 1, 3-4 (1984).

122 Easterbrook, Workable Antitrust Policy, 84 Mich. L. REv. 1696, 1702-03 (1986). 


\section{Easterbrook then asserted:}

This turns out to be the same program as one based on "efficiency." There are differences at the margins . . . but the differences are not very important . . . [especially because] [i]n the long run consumers gain most from a policy that emphasized allocative and productive efficiency. ${ }^{123}$

Easterbrook thus appears to concede that the wealth transfer view of the antitrust laws' legislative histories is more accurate, but argues that it leads to conclusions that differ only slightly from the efficiency approach.

If the gap between the Chicago School and the adherents of a wealth transfer approach has narrowed to an acceptance of the latter perspective with disagreement over how important it will be for antitrust, this article's thrust has been overly cautious. Antitrust soon will march in a new direction. Only after we have worked out these differences will we truly know where its destination lies.

This is not the place to analyze either the magnitude of the differences between the two approaches or the practical effects of these differences on various types of antitrust cases. But it is noteworthy that the inefficiency effects of market power are surprisingly modest. ${ }^{24}$ Easterbrook recently estimated that they

123 Id. at 1703. It probably is true that the wealth transfer and efficiency approaches differ more in the short run. Long run and indirect effects are more difficult to predict.

124 "The first estimate of the loss to the American economy caused by monopolistic misallocations was presented by Arnold Harberger in 1954. If the results of Harberger's estimates were expressed in terms of 1982 dollars, they would be equal to approximately $\$ 12.00$ per person per year. . . . It is hardly surprising that other economists arrive at different estimates, some of which are lower than Harberger's, while others are larger (some even by a factor of 50). Scherer's review of the evidence puts the figure 'between 0.5 and 2 percent of the gross national product [between approximately $\$ 50$ and $\$ 200$ per person per year] with estimates nearer the lower bound inspiring more confidence than those on the higher side. . . 'The more important question is what the magnitude of this loss would be if there were no antitrust laws to act as both deterrent and corrective systems. It may be impossible, however, to formulate a meaningful estimate of this figure." Lande, supra note 8, at 73 n. 32 . 
are half as large as the transfer effects, ${ }^{125}$ a figure that is probably an overestimate. ${ }^{125}$ Even if we accept his estimate, however, we must conclude that "what's wrong" with market power is approximately trebled when the transfer is also included-a result bound to lead to many significantly tighter antitrust rules. ${ }^{127}$

At least two types of areas will be affected. First, antitrust rules based upon a balance of procompetitive and anticompetitive effects will shift and proscribe much more behavior. Horizontal merger guidelines, for example, would be significantly lower if the wealth transfer effects of mergers also are included. ${ }^{128}$ Second, practices without significant inefficiency effects could become illegal if they are used by firms with market power to extract wealth from consumers. Areeda's perfectly price-discriminating cartel is one such example. As the discussion supra Section I(C) suggests, some uses of tying or other vertical restraints to price discriminate might be illegal only under a wealth transfer view. ${ }^{128}$ And the Allied discussion, supra Section I(C), shows that a practice in an industry with relatively inelastic demand might also be treated very differently if wealth transfers are considered.

125 Easterbrook, Panel Discussion, 55 AntrTrust L.J. 123, 126 (1986).

126 See Fisher \& Lande, Efficiency Considerations in Merger Enforcement, 71 CALIF. L. REv. 1580, 1644-50 (1983).

127 This is only an approximation, and probably an underestimate of the differences. One weighing approach would be to give wealth transfers equal weight to efficiency effects in the tradeoff calculations. Another approach, probably more in line with Congressional intent, would forbid any merger likely to lead to a significant extraction of consumers' surplus by firms with market power. The latter approach would use price to consumers as its benchmark. In cases involving price discrimination, however, it might be more meaningful to focus upon wealth transfers than consumer prices.

128 Fisher \& Lande, supra note 126, passim.

129 See also Lande, Untangling Tying (1988) (unpublished manuscript) (draft). 


\section{The future}

Robert Bork's Supreme Court nomination was not rejected because he refused to embrace more than efficiency in antitrust analysis. But his rejection might portend that his antitrust views also will come to be rejected.

When the efficiency-only view replaced the social/political perspective many in the antitrust community refused to convert. Some refused out of inertia, but most probably balked at supporting Bork's illogical reading of the antitrust laws' legislative histories.

We appear to be at another watershed, one which may split the antitrust community partly along generational lines. Relatively young, intellectually honest conservatives will tend to join moderates and liberals of all ages in accepting the new wisdom. Some will do so by admitting their past errors; others will attempt to cloud the differences and their past positions. But many in the efficiency school will be more rigid and close-minded, especially those who have invested years or decades believing in its exclusivity. The future of antitrust will leave them behind, but because of their strength what should be a peaceful transition will instead be a lengthy struggle.

Like the previous round, this contest probably will be influenced not only by the actual intentions of the Congresses that enacted the antitrust laws but by a Presidential election as well. If conservatives $^{130}$ are placed in charge of the federal antitrust enforcement agencies following the 1988 elections the efficiency standard will die much more slowly. It is even possible that a President Bush could appoint several justices to the Supreme

130 Terms like "conservative" have been used arbitrarily and with license throughout this article. It is, of course, incorrect to view "conservatives" as opposed to vigorous antitrust enforcement and "liberals" in favor. See, e.g., L. Thurow, The Zero-Sum Society at 146-50 (1980). It is also incorrect to assume that the election of George Bush in 1988 will produce Reagan-era antitrust enforcement since many Republicans favor strong antitrust enforcement. 
Court who agreed with Bork on the issue and the efficiency school would reign for the foreseeable future.

If the Democrats capture the White House and retain control of both houses of Congress, however, the transition will be much more rapid. On the efficiency side probably would be several Supreme Court justices, many Reagan-appointed federal judges, a large percentage of established antitrust academics, and a generally conservative defense bar. On the consumers' side would be other Supreme Court justices and lower court judges, many influential congressmen, the state and federal antitrust enforcers, and at least a few increasingly astute plaintiffs' lawyers. ${ }^{131}$ There will also be growing pressure from an increasing number of academics.

In many areas of the law academics have little impact. During the past generation, however, an influential group of articulate, aggressive antitrust scholars have developed and delineated the effects of an efficiency-oriented view of antitrust policy and have successfully advocated its implementation. The future of antitrust is economics and efficiency will always be important. We will not return to Brown Shoe ${ }^{132}$ antitrust for the foreseeable future, and many of the reasons why antitrust has long been in decline will be unaffected by the fall of efficiency's antitrust monopoly. ${ }^{133}$ But the practical ramifications of a price (or wealth transfer) standard are just beginning to be worked out. Aggressive academics, both lawyers and economists, can be expected to rise to the opportunity and make compelling consumerist arguments to open minded judges and justices. These "young Turks" will provide ideas for and work symbiotically with consumer-oriented federal and state antitrust enforcers and private plaintiffs for a revitalization of antitrust.

131 For example, Fred Furth, who usually represents more antitrust plaintiffs than defendants, underwrote most of the expenses for the 1987 Airlie House Conference that called for more vigorous antitrust enforcement. Lawyers like Furth can be expected to use the wealth transfer concept in litigation whenever so doing will benefit their clients.

132 Brown Shoe Co. v. United States, 370 U.S. 294 (1962).

133 For additional analysis, see Sims \& Lande, supra note 87. 